\title{
O posicionamento do narrador em A rainha dos cárceres da Grécia, de Osman Lins
}

\author{
Robson Hasmann*
}

\section{Resumo:}

O presente estudo de A rainha dos cárceres da Grécia procura desvelar aspectos estruturais e temáticos que compõe o último romance de Osman Lins. Sem se prender a teorias ou tentar adaptar alguma teoria ao texto (tendo, aliás, muitas vezes, um caráter ensaístico), procura a análise detalhar os procedimentos que dão forma ao narrador e que ganham forma a partir dele.

Palavras-chave: narrador, Osman Lins, A rainha dos cárceres da Grécia

\section{Abstract:}

This study of $A$ rainha dos cárceres Grécia search for showing tematics and structures aspects that compose the Osman Lins' last novel. Without to became attached to the theories or to try adapted to some theory to text (by the way, sometimes, the study has assay character), investigate the analysis to specify the proceedings that shape to narrator and that is shaped to it.

Key words: narrator, Osman Lins, A rainha dos cárceres da Grécia

Brasileiro, Universidade de São Paulo (USP), Secretaria de Estado da Educação de São Paulo (SEE-SP) e Centro de Estudos Ambientais do Vale do Paraíba (CEAVAP). robsonhasmann@ig.com.br 


\section{Introdução}

A teoria da literatura tratou de discutir, e separar, entidades empíricas e ficcionais que aparecem na composição de uma obra: o autor e o narrador. Vistos ora como entidades semelhantes, em alguns estilos de época e pela crítica da época, ora como diferentes, na verdade continuam gerando dificuldades de definição. A pós-modernidade acentuou essa dificuldade e ampliou a discussão. Conceitos surgidos dentro da concepção que a crítica francesa chama de écriture de soi, como autoficção, autobiografia, romance autobiográfico e nova autobiografia (nouvelle autobiographie) surgem para tentar dar conta das diversas manifestações de mediação feita pelo autor para gerar e gerir sua obra.

Com efeito, o desenvolvimento do gênero épico está intimamente ligado às mudanças sofridas pelo narrador. As formas de narrar foram se aperfeiçoando ao longo dos séculos e, com elas, os métodos de estudos sobre o posicionamento do narrador, sobre sua relevância dentro do texto narrativo e sobre os modos de articulação com outros elementos como o tempo, a ambientação, as personagens, bem como sua importância para a construção do enredo.

A partir dessas questões, este ensaio está centrado na posição do narrador e na forma como ele faz a mediação entre o autor e o leitor. Pretende discutir a relação autor-narrador-leitor dentro do romance $A$ rainha dos cárceres da Grécia, de Osman Lins.

A hipótese inicial é que esse romance desenvolve concepções sobre a criação literária que são essenciais para a compreensão do próprio desenvolvimento da épica. O ponto de partida escolhido foi o narrador, elemento didaticamente independente de outros dentro da narrativa (ambiente, tempo, personagens e enredo) mas indispensável, porque é o responsável por mostrar ao leitor e/ou conduzi-lo pelos corredores do labirinto chamado narrativa. Aliás, a correspondência direta entre as palavras narrador e narrativa é suficiente para que se imponham luzes nele ao ser estudado um romance, um conto, uma epopéia etc.

Para a análise, será utilizada a nomenclatura dada pelo próprio narrador. Ele afirma, em determinado momento, que há, em A rainha dos cárceres da Grécia, um dispositivo de mediação. Pretendemos verificar, com o narrador do romance, que um dos procedimentos mais importantes dentro de um texto narrativo é a mediação. O Novo Dicionário Eletrônico Aurélio da Língua Portuguesa define a mediação como a "relação que se estabelece entre duas coisas, ou pessoas, ou conceitos, etc., por meio de uma terceira coisa, ou pessoa, ou conceito, etc." Restringindo o vocábulo à História e à Filosofia, pode ser definido, como "no gnosticismo, função 
exercida por diferentes potências celestiais na condução do homem à gnose."

Sem querer estender em demasia as questões iniciais, pensamos ser mais indicado interromper essa introdução e começar a seguir, passo a passo, o caminho desta leitura do romance de Lins, sem, obviamente, pretender ser dogmática.

\section{1. À maneira de resumo}

Talvez a obra de Osman Lins seja desconhecida do público chileno e por parte da crítica. Por isso, faz-se necessária a elaboração de um momento neste trabalho que vislumbre narrar sinteticamente a narrativa estudada.

O romance A rainha dos cárceres da Grécia, de Osman Lins, publicado em 1976, narra a história de um professor que quer dedicar algumas horas de sua vida a escrever sobre um livro manuscrito deixado pela amante Julia Marquezim Enone. O narrador-ensaísta é professor de Biologia para o ensino secundário e se declara um apaixonado pelos livros, sobretudo por romances. A paixão por eles o motiva a escrever sobre o romance deixado pela amante falecida.

Osman Lins cria, então, um romance dentro de seu romance. O professor opta por um diário, ao invés de um ensaio, gênero textual que o próprio professor crê mais indicado para a análise de uma obra literária. Existe, a partir da inserção de uma história dentro da outra, um jogo especular, entre real e imaginário, que faz com que várias linhas narrativas sejam criadas e se multipliquem.

Existem, a priori, duas histórias: a do professor de ensino secundário que escreve sobre um manuscrito deixado pela amante e a da personagem criada por Julia Enone. O manuscrito deixado é homônimo ao livro de Osman Lins: A rainha dos cárceres da Grécia.

Como já dissemos, o professor tenta criar um ensaio que toma a forma de um diário. A escolha pela forma anuncia o autobiografismo (não de Osman Lins, mas do professor), que oscila com os momentos de reflexão sobre o livro e sobre a cena sócio-política do Brasil durante os anos de 1974 e 1975 (época dos registros no diário). Seu conflito é gerado, em geral, não só pelas reflexões e lembranças de Julia, mas também pelo contexto ditatorial do Brasil à época. 
A principal dúvida do narrador-autor, logo nas primeiras páginas, é saber sobre o que exatamente escrever: ou reconstituir o que Julia Ihe havia contado sobre sua vida, o que testemunhara e o que mais tarde, após a morte da amante, veio a saber sobre ela; ou escrever um ensaio sobre o manuscrito deixado por ela. Os primeiros questionamentos começam em 26 de abril de 1974. Em 15 de julho, decide-se por escrever um ensaio em forma de diário, para estabelecer "com o leitor -ou cúmplice- um convívio mais leal" (LINS, 1977:8).

Ao longo de alguns dias (10 registrados em diário), quando finalmente parece ter se decidido, aparece-lhe outro temor: que finalidade teria um ensaio acerca de um livro não publicado?

Para responder a essa pergunta, procura um docente da Pontifícia Universidade Católica de São Paulo, o qual é indicado somente pela sigla A. B. Afirma-lhe o docente que o meio acadêmico literário detinha-se mais nas "teorias" e/ou naquilo que se escreve sobre as obras do que nas obras em si. O comentário é animador, já que, em hipótese, os leitores estariam mais animados a ler o ensaio do que a obra da amiga falecida. A ironia está posta. Osman Lins coloca uma questão nevrálgica de sua época: deslumbrados com as teorias estruturalistas (e por outros motivos, como se verá também), à crítica na década de 70 interessavam-Ihe mais as teorias do que a obra. Portanto, sem conseguir manter a distância necessária do objeto analisado (atitude importante para o crítico que se propõe a analisar uma obra), o narrador-ensaísta, aos poucos, se demonstra uma pessoa conflituosa.

Assim, uma afirmação feita em $1^{\circ}$ de maio se consuma e corrobora com a produção ensaística: "Ocupar-me do livro oferece vantagens evidentes. O texto impedirá que eu me embarace entre as recordações e imagens conservadas, dédalo a disciplinar."(LINS, 1977:2). A especificação de que o texto o impedirá de embaraçar recordações e imagens passadas da amante propõe ao leitor que o professor está convicto do que deseja escrever e de como escreverá o que almeja. No entanto, mostrar-se-á perdido, embaraçado entre justamente aquilo de que pretendia fugir. Artifício de Osman Lins? Não apenas isso. Em consonância com o contexto da obra, essa discussão preliminar feita pelo professor se encaixa às outras partes que compõe a narrativa. A análise crítica do ato de escrever está intimamente ligada à concepção metalingüística do romance de Lins e à crítica feita ao estruturalismo. O romance se presta, portanto, não só a contar um enredo. Ele se presta a fazer o papel de crítico da própria obra e da própria crítica literária da década de setenta.

Pretendemos aprofundar essa discussão mais tarde. Por ora, verifiquemos como as discussões preliminares dialogam com a tradição literária brasileira e o ato criador em si. 
A história caminha construindo-se. Na busca por compreender o livro de Julia, o professor viaja a Pernambuco (no Nordeste) para encontrar a família da amante morta. Encontra com o ex-marido dela, só não vê a filha que Julia dizia ter.

No que diz respeito a sua vida particular, aos poucos abandona as aulas. Tem, em dois momentos, problemas com os olhos, chegando, inclusive, a ser internado. Em uma das vezes, recebe a visita de Alcmena, sua sobrinha - personagem fundamental na composição da obra, a qual mais tarde analisaremos mais detidamente. Durante a visita (que é a segunda na obra) ela lê para o tio. Além disso, é Alcmena quem abre os olhos do tio para o fato de ele estar totalmente dentro do romance de Julia: "Vejo o senhor no livro inteiro" (LINS, 1978:45). Ele, a partir daí, se reconhece em uma das personagens do livro: um espantalho.

Enfim, no último dia de registro no diário, o estilo de Julia Marquezim Enone invade o estilo do diário, que, inevitavelmente, deixa de ser diário. Verifica-se, nitidamente, que o professor começa a fazer parte do romance de Julia. O que era, para ele, ficção concretiza-se e nós, leitores, vemos surgir Maria de França, a qual une-se ao professor. Esse encontro beira ao fantástico, o insólito. Mas é perfeitamente verossímil.

A que se deve a verossimilhança? É o que a partir de agora discutimos.

\section{O narrador na tradição}

Osman Lins, em A rainha dos cárceres da Grécia, demonstra-se profundo conhecedor da tradição literária brasileira e mundial e do gênero que se cultivava à década de setenta no Brasil, o romance reportagem. Cronologicamente, situemos a tradição.

Alguns exemplos da literatura brasileira, já consagrados, e que possuem um narrador masculino escrevendo sobre uma mulher, adotaram o procedimento comum aos narradores "primitivos": a preparação para contar.

Como primeiro exemplo, escolhemos destacar Paulo, narrador de Lucíola, de José de Alencar. No primeiro capítulo, o narrador conta aos leitores a motivação que teve para contar sua história com Lúcia (Maria da Glória).

Outro exemplo é Dom Casmurro (1899), de Machado de Assis. Com o objetivo preciso de "atar as duas pontas da vida", Bento Santiago explica ao leitor o título e as razões que o levam a escrever suas memórias, focando no relacionamento que teve com Capitolina, Capitu. 
Paulo Honório, de São Bernardo, de Graciliano Ramos, traz novamente o motivo da busca por uma explicação de um passado perdido. Novamente, o capítulo inicial é uma reflexão sobre o que, ou como ou sobre a origem do relato.

O último exemplo que aqui se expõe não se modifica. Grande sertão: veredas (1956), de Guimarães Rosa. Riobaldo, o narrador, passa páginas e páginas fazendo reflexões (quase em um non-sense), falando a um ouvinte, que, em última instância, é o próprio leitor.

Por esses exemplos, uma conclusão se faz necessária, seguindo o ensinamento de Riobaldo: "contar é muito dificultoso". Por isso, a preparação antes de contar. Por que, aliás, não lembrar da função das musas na épica tradicional? A invocação era primordial para que o aedo ou poeta tivessem êxito ao cantar para contar. Também Camões invocou as Tágides, seguindo os modelos da llíada e da Odisséia.

Da mesma maneira (preparando o ouvinte, contextualizando a narração) procede ao narrador-ensaísta de A rainha dos cárceres da Grécia. Todavia, tal qual a novidade no procedimento não existe, é preciso nos perguntar: em função do que está esse procedimento? Osman Lins era grande conhecer não só da tradição literária universal, clássica, erudita, como também era participativo nas produções literárias e teóricas de sua época. Haja vista a adaptação, em suas obras, de alguns recursos do Novo Romance francês, como mostra Sandra Nitrini'.

Além disso, produziu muitos textos discutindo a função do escritor e do livro na sociedade. Portanto, a dificuldade do professor em expor de uma vez o que exatamente pretende escrever mostra que o romance situa-se entre a preocupação estética e a teórica. Esse recurso não é apenas parte da vida desse narrador específico.

Como dissemos, além do diálogo com a tradição da épica, Osman Lins critica a postura dos críticos e dos escritores da época e aponta como se dá a intermediação pelo texto literário com a realidade. Mais do que ser composta de elementos verossímeis ou biográficos, a obra é uma intermediação entre o autor e o leitor. Boa parte do entendimento do texto vai depender do grau de conhecimento e domínio dos recursos literários de ambos.

Por outro lado, a obra, assim como seu autor, não pode se desvincular do contexto histórico em que foi criada. Marcas intencionais ou não sem- 
pre hão de aparecer, mesmo que o enredo esteja ambientado em outra época. A obra, sob esta óptica, é mediadora entre o mundo e o leitor. Mas dentro da própria obra há outra forma de mediação: o narrador.

Ajustado a seu tempo, Osman Lins cria, ainda, um romance próximo ao gênero que era comum: o romance reportagem. Em sua dissertação de mestrado, Maria Teresa Dias (1997) explora em um dos capítulos a sutil relação que existe entre o romance de Lins e esse gênero cultivado por autores como Rubem Fonseca, Ignácio de Loyola Brandão e Ivan Ângelo. No entanto, ressalta que "Embora apresente notícias de jornal, o romance de Osman Lins, de forma alguma, equipara-se aos chamados romances-reportagem escritos no mesmo período" (p.135).

Segundo Dias, esses romances se caracterizam por apresentar um enredo baseado de fatos tirados de notícias de jornal e ir criando uma espécie de reportagem mais elaborada. A rainha dos cárceres da Grécia apresenta esse procedimento, mas, além de não ser recurso predominante, tem objetivos diferentes dos romances-reportagem. As notícias retiradas dos jornais são colocadas em função de um todo: a temática da dominação dos oprimidos e injustiçados pelos poderosos. Além disso, as reportagens aparecem paralelamente a História da invasão holandesa (um dos temas encontradas pelo professor no romance de Julia).

Como o eixo central da narrativa de Lins é, a princípio, a história de Maria de França (duas vezes ficcionalizada, como se verá), é seguro afirmar que o aparecimento do procedimento de construção dos romancesreportagem tem a função de dialogar com o gênero cultivado à época, assim como há um diálogo com a tradição literária brasileira.

Cientes desse diálogo com a tradição, cabe-nos mais uma pergunta: o narrador teria, então, exclusivamente a função de estabelecer o diálogo, ou o romance de Osman Lins coloca em cena uma tese "inovadora" sobre o narrador?

Há algumas linhas, expusemos que antes de iniciar seu "ensaio" o professor-ensaísta faz vários questionamentos sobre a necessidade ou não de escrever a respeito de um manuscrito e a utilidade que o ensaio desse manuscrito teria no mundo acadêmico. Dentro de $A$ rainha..., dissemos, também, há, basicamente, duas narrativas. Portanto, há dois narradores 
e é preciso estudá-los separadamente, ainda que, temos como hipótese, o método de criação tenha sido o mesmo. ${ }^{2}$

Tratemos do romance de Julia Marquezim Enone, antes do de Osman Lins.

\section{O narrador fluido}

Chamamos, aqui, de "narrador fluido" aquele que se dilui pelo discurso narrativo, mudando a perspectiva da qual narra ou assumindo voz alheia (ou vozes). A fluência também diz respeito à deformação de um corpo submetido tensão constante. Assim, no em A rainha dos cárceres da Grécia, a construção do ensaio requerer constantes adaptações do narrador. A mudança de olhar sobre os assuntos abordados pelo texto de Julia exploram. É importante observar que não encontramos na crítica especializada essa nomenclatura. Isso não quer dizer, no entanto, que propomos algo novo.

Utilizar os termos ponto de vista, foco, perspectiva não nos parece adequado porquanto exigem um ponto de vista único. Por outro lado, tampouco vale citar recursos como fluxo de consciência ou monólogo interior, devido à forma de marcação temporal do romance, já que ele se constrói em forma de diário. Por fim, citar a mudança de foco ou ponto de vista, tão utilizada pelos novos romancistas franceses, é descartar que, para eles, a descrição era um elemento fundamental inclusive para fazer do enredo um elemento menos importante. Isso, na poética de Osman Lins, não acontece. Sandra Nitrini já apontara na construção de Nove, novena que "um dos pontos centrais da poética osmaniana reside numa espécie de relação dialética entre o discurso e a categoria literária história, enquanto conjunto de acontecimentos relacionados com uma ou varas personagens." (NITRINI, 1987:72-grifo da autora). Aliás, dentro de $A$ rainha dos cárceres da Grécia, o narrador-ensaísta defende, indiretamente - pois admira a trama criada por Julia-, não concordar com a estrutura dos romances de sua época, os quais abriam mão do enredo.

2 Osmans Lins, em entrevista a E\$sdras do Nascimento, apud Dias (1997) divide em três camadas ou planos narrativosd: 1) a do real-real; 2) a do real-imaginario a 3) a do imaginário-imaginário. Dias por sua vez, divíde em quatro: 1) a História de Maria de França; 2) A denúncia de caráter jornalístico; 3) a histíria do ensaio e 4) a história do mor do professor e Julia Maarquewzim Enone. Em nosso ensaio, mais modesto e com menmos pesquisa, preferimos, como apontamos acima, dizer oriuendas dessses dois planos que se espelham e geram outras linhas. Esse jogo especular é que nos parece o responsável pela sobreposição de camadas, linhas e planos narrativos. 
A partir dessas informações, percebemos como é truncado o romance de Lins. Trata-se de um narrador que olha com olhos de outra narradora (Maria de França), cuja lógica no estabelecimento do discurso é questionável, pois é louca.

Já a autora de Maria de França, Julia Marquezim Enone, ex-amante do professor, não aparece na narrativa. Tudo o que sabemos dela é por meio e através do amigo e é mediado por ele. Sua história, seus ideais e seus gostos fazem parte das lembranças e recordações do professor. Com esse fato, coloca-se a seguinte pergunta: seria Julia Marquezim Enone uma invenção do professor? Se ela é uma criação dele, com qual finalidade foi criada? As idéias que sustentam a hipótese de ser ela uma criação decorre do fato de a todo instante o professor tentar ludibriar os leitores e sempre mudar de opinião. Por outro lado, corrobora para a existência dela o fato de que Alcmena (sobrinha do professor) aparecer, ler o manuscrito, perguntar sobre Julia e receber informações do tio. Além disso, o professor vai até Pernambuco, onde Julia foi criada e se encontra com seu ex-marido e com membros de sua família. Enfim, pensar que Julia não existiu, que não deixou o romance e que seria apenas um recurso do professor para falar de si mesmo necessitaria um esforço de argumentação muito forte, que, em última instância, seria vazio, pois os fatos e a verossimilhança do romance negariam a tese.

A questão é: o professor de Biologia teria inventado Julia para arrumar um pretexto para falar de si mesmo ou é a recordação de Julia que faz com que ele se volte para si mesmo? Se Julia Marquezim Enone não existe, existirá Maria de França? Ambas são criações dele? O fato de o romance ter a estrutura de um diário corrobora com a hipótese de que o mais importante é o (auto)biografismo do "amigo" de Julia Enone e não o interesse de divulgar o livro dela, como dissera no princípio em conversa com o professor A. B., da PUC.

Qual a idéia defendida no último dia de registro: o professor tenta escrever sobre si mesmo visando a se libertar de uma iminente loucura (idéia que é comprovada pelo non-sense do último dia)? Ou é defendida a idéia de que é necessária, para o entendimento de uma obra literária, a entrega do leitor ao texto e, por isso, o professor se une a Maria de França, dando-Ihe as mãos? Podem ser as duas idéias?

Como já explicitamos acima, a entrada para a realização da leitura de A rainha e o ponto central que se deseja discutir é a posição do narrador. Tentaremos responder às questões colocadas nos parágrafos anteriores levando em consideração o narrador. Até aqui, preocupamo-nos em explicitar alguns acontecimentos e levantar alguns questionamentos feitos em determinados momentos do romance. Neste ponto nosso objetivo é 
fazer um panorama do histórico da evolução dos estudos acerca do foco narrativo e qual a importância desse elemento para a compreensão da obra narrativa em geral e de $A$ rainha especificamente.

\section{Transformações do narrador e do narrado}

O ato de contar é inerente ao ser humano. Assim, pode-se dizer que histórias existiram desde que o homem começou a elaborar sua linguagem, seja a pictórica ou a escrita. No entanto, os primeiros vestígios sobre estudos que buscam compreender o ato de contar e a criação de uma narrativa originam-se na Grécia, com Platão e Aristóteles.

Platão, em A República, faz a distinção entre narrar e imitar. Para o filósofo, o poeta, ao produzir uma obra épica, uma narração, se sente melhor quando precisa imitar homens cujas atitudes estejam em acordo com o que a pólis entende como ações e comportamentos virtuosos.

Discípulo de Platão, Aristóteles faz a mesma distinção, mas acrescenta um ponto: a épica tem um terceiro elemento. Esse elemento é a voz que conta uma experiência não mais vivida e sim por outra pessoa, como acontece na épica de Homero. Ainda para Aristóteles, a poesia é reveladora das essências humanas, ao contrário do que pensava Platão, para quem a poesia era imitação da imitação. Essa característica reveladora da essência é o princípio da catarse, uma das funções da literatura, responsável pela purgação e revelação dos sentimentos e emoções reais vividas pelos espectadores no momento que assistem à peça.

Antes de partir para o próximo filósofo (escolhido para este ensaio) que se deteve no estudo da narrativa e que sistematizou e organizou concepções de Platão e Aristóteles, faz-se necessário voltar ao romance de Osman Lins.

Essa função catártica da narrativa é crucial em $A$ rainha dos cárceres da Grécia. O professor experimentará a catarse com Maria de França, protagonista do manuscrito de Julia Marquezim Enone. À medida que penetra no labirinto que é o romance não publicado, à medida que começa a desvendá-lo, o professor, paradoxalmente, se envolve em outro: sua própria personalidade, seu próprio "eu", que está perdido. Por isso levantamos a questão: ele, ao contrário do que diz, não quer se ocupar do romance, ele quer ocupar-se de si mesmo através do romance. Com isso, o professor vive a catarse e Osman Lins adverte-nos da importância de não se deixar perder esse elemento essencial para a fruição da arte.

A idéia de que é preciso vivenciar a experiência estética de maneira 
intensa, promovendo a catarse, poderá ser mais bem compreendida se voltarmos à evolução das discussões teóricas acerca da épica e, dentro dela, do foco narrativo.

Em Estética, Hegel retoma as idéias de Platão e Aristóteles. A partir deles, trata de distinguir os gêneros literários: épico, lírico e dramático. O gênero épico conteria objetividade na narração dos fatos. O segundo, subjetividade, pois trata dos sentimentos, das emoções, das sensações de um eu poético. Já o gênero dramático, conteria as características dos outros dois gêneros.

Diretamente ligado à épica, a epopéia transformou-se no romance, a que ele chamou de "epopéia burguesa moderna". É sabido que o desenvolvimento do romance se deveu justamente ao surgimento e estabelecimento da burguesia entre os séculos XVIII e XIX. No romance, o épico e o dramático convivem. Essa convivência, esse caráter híbrido do romance é que distingue a épica tradicional da épica moderna.

Essa distinção, por sua vez, será o eixo da teoria do foco narrativo. Expliquemos melhor. Antes do surgimento da epopéia, o que se vivia era contado. $\mathrm{O}$ aedo, ou o poeta, o responsável e iluminado para contar, passava aos outros a sua experiência de outras terras, de outros lugares. Com a epopéia, contam-se coisas vividas por outros. Não necessariamente pessoas, mas ela se mostra como uma mescla de outros textos: epigramas, inscrições em monumentos, poemas didático-filosóficos, teogonia e cosmogonias.

Com o advento do romance, a mudança se dá em vários níveis. Primeiramente, acontece que mesmo que o poeta grego contasse a história de outro, havia pessoas reunidas ao redor dele para ouvir as histórias. O romance é característico daquele que está isolado. Portanto, a partir do surgimento do gênero ligado à burguesia, a experiência de narrar se modifica. $\mathrm{O}$ ato experimentado pelo criador não coincide mais com o momento experimentado pelo ouvinte. Este irá, em outro momento, isoladamente também, experimentar as ações dos heróis.

Essa mudança da experimentação da criação artística (que passa a ser sentida pelos meios tecnológicos) é o que Walter Benjamim, em "O narrador" chamou de perda da aura. Com o advento da modernidade, a criação artística perde seu caráter único, seu momento essencial que é o da criação. No que tange à literatura, a narração era uma maneira de passar a experiência. A troca de experiências se dava, basicamente, por dois grupos de narradores arcaicos: o camponês sedentário e o marinheiro comerciante. Os meios de produção em massa e a reprodutibilidade técnica (dar à técnica status de arte) abriram espaço para o desapareci- 
mento da arte de narrar. Por isso, relacionando o romance e a narrativa tradicional, Walter Benjamin sentencia: "O primeiro indício da evolução que vai culminar na morte da narrativa é o surgimento do romance no início do período moderno" (1994:201).

Em A rainha..., o que se vê é justamente uma apologia a vivenciar a experiência. A catarse. O movimento de transfiguração do professor em personagem do livro de Julia Enone mostra como Osman Lins buscou transmitir a idéia de que é preciso viver a obra de arte intensamente. Além disso, escritor comprometido com seu tempo que era, o pernambucano não deixa de criticar essa falta de experiência estética dentro do mundo acadêmico da década de 70, época em que o pensamento estruturalista ditava as experiências de leitura e em que a leitura de uma obra estava jogada a segundo plano, pois se privilegiava a leitura de teorias.

A crítica aparece já nos primeiros dias de registro do diário³.

Vivenciar intensamente a obra era, portanto, não apenas um ideal seguido por Lins, mas também uma forma de se posicionar contrário às formas mecanizadas e automatizadas de leitura dos textos literários como eram feitos pelos professores da Faculdade de Letras de Marília, quando lecionou literatura.

Osman Lins, vendo de maneira amorosa e esperançosa a situação da arte literária parecia perceber que, na modernidade, buscar a unidade talvez já não fizesse sentido. Mas essa perda da unidade representaria o papel redentor e catártico da obra de arte. A proposta, então, situada em $A$ rainha dos cárceres da Grécia seria que, ser fragmentado, incluir discursos alheios ao próprio, criando a sensação não de perda, mas de um ser que se vai completando, ainda que caoticamente, seria a solução para encontrar a unidade perdida. $O$ amor que salva e une o espantalho (personagem no qual o amante de Julia se reconhece) e Maria de França é semelhante ao amor ao ato de narrar e viver a literatura que Osman Lins propõe.

3 Em 18 de maio de 1974, ao resumir sua discussão como mo professor da PUC paulista sobre a importâncias de um ensaio sobre um manuscrito, o narrador-ensaísta que "se, por exemplo, (os alunos de Letras) sabem alguma coisa de madame de Volanges, de Danceny e do libertino Valmont, não é por terem lido As ligações periogsas, e sim porque ouviram a análise estampada há cerca de oito anos na revista Communications sobre o romance de Laclos." (LINS, 1978:4). Como se sabe, o número 8 da citada revista é >"a bula papal" do estruturalismo francés. Com textos de Roalnd Barthes e Tzvetan Todorov, esse número deu as bases do estruturalismo literário, baseado na lingüística de Saussure. 


\section{O processo de mediação}

Nos dias 4 e 12 de outubro de 76 e 2 de fevereiro de 75, o professor levanta hipóteses acerca dos procedimentos criados por Julia Marquezim Enone para compor seu romance. Para ele, tal dispositivo é um recurso cuja característica é tentar converter a vida em discurso. ${ }^{4} \mathrm{Diz}$, entre outras afirmações: "A rainha dos cárceres da Grécia, insisto, é um tecido de simulações" (LINS, 1977:108).

Fora isso, diz não concordar com a nomenclatura e terminologia existente à época sobre o narrador. Para o narrador-ensaísta, o ideal seria utilizar o que Diderot preparara como esboço para O elogio de Richardson, mas que não fora aproveitado. Segundo ele, Diderot fala sobre o discurso de mediação. O termo, pelas breves pesquisas que fizemos, não consta dos manuais de literatura. E também é questionável que ele realmente tenha recolhido a expressão de Diderot. Isso porque se trata de um esboço não aproveitado, o qual teria saído em uma revista inglesa chamada Drum. Cremos, com efeito, que o termo é cunhado por Lins. A terminologia do foco, do ponto de vista etc. não daria conta do ideal -do qual tratamos no subitem "o narrador fluido" - de narrador almejado por Osman Lins.

A construção da mediação acontece não com um narrador que viveu uma experiência e que, tempos depois, passa a contá-la, como freqüentemente acontece nos romances. O mediador (o narrador) se constrói durante a enunciação. O processo de composição do enunciado (o diário) é a composição fluida e diluída do narrador pelo texto que escreve.

No desmembramento da narrativa, Osman Lins cria várias mediações. Vejamos como isso se dá.

Desde os primeiros dias de seu diário, o professor impõe alguns questionamentos a respeito do ato de narrar. Após "quase três semanas de hospital" (LINS, 1977:28) faz um levantamento do saldo de sua vida, das mudanças pelas quais passou durante os 50 anos que tem. Ressalta a importância de Julia, com quem ficara três anos e seis meses. Mas as recordações que tem de Julia estão profundamente enraizadas ao livro. Buscando explicar como se processa sua lembrança, expressa o seguinte: Não que o texto se desfizesse e volvesse, por assim dizer, às coisas que nomeia. Sem deixar de ser o que é, oferecia-se também enquanto mundo e eu nele me movia, entre carnal e verbal. Uma espécie diversa de leitura?

4 Da mesma idéia parece compartilhar Osman Linbs em entrevista citada na dissetração sde Dias (1977), o escritor afirma que sua intenção não é "transformar o verbo em carne, mas a carne em verbo". 
Um modo esquecido, já apagado em nós, de percepção das narrativas? Não sei. (LINS, 1977:28).

As semanas passadas no hospital pelo professor foram decorrentes de uma cegueira que lhe atacou durante os meses de setembro. Ele afirma ter maus olhos. Por isso, quando forçados acabam por intensificar a pouca visão. No dia 12 de outubro, alguns dias após registrar as palavras citadas anteriormente, volta a fazer reflexões sobre o que sentiu nas semanas em que esteve hospitalizado.

Tardia e desconexa, vem-me inquietar uma pergunta sobre o modo como, durante o mês de setembro, nos dias de cegueira, vi-me dentro do romance, movendo-me nele. Significaria isto o desespero de não ver, aí, traços meus? A ausência não deixa de ser inquietante para quem tanto amou a romancista (e ama-a ainda, na medida em que amamos os mortos) e eu quase poderia indagar: "Como saber se existi -se, ao menos, existi para ela-, quando, no seu livro, em nada me reconheço?" (LINS, 1977:36-grifo no original).

Nesses dias estão preparadas as cenas finais do romance. Como o narrador expusera no dia 4 de outubro, ele irá se mover entre carnal e verbal. Apesar de não se reconhecer, no romance, foi preciso adoecer dos olhos para melhor enxergar. Mais uma vez, tentando ludibriar o leitor, o narrador diz que "quase poderia indagar". Por que "quase" se realmente indaga? Em um processo metalingüístico, Osman Lins, no dia 2 de fevereiro de 1975, após o narrador receber a visita de sua sobrinha Alcmena (a respeito de quem, a seguir, serão tecidas algumas considerações mais detalhadamente), descobre o dispositivo de mediação de Julia. Concebido como um monólogo radiofônico, a personagem Maria de França converte a vida em discurso (ou instaura, mediante o discurso, um simulacro de vida). Ambos processos não são excludentes. Eles se complementam e são reforçados pela idéia de que Maria de França se desliga dos leitores e de seu discurso. O mesmo acontecendo ao professor durante toda o romance.

Para a comprovação de que ele passará a se mover entre carnal e verbal dentro do livro de Julia, seria necessário citar todo o último dia de registro no diário. O non-sense instaurado ali se conforma com o discurso de Maria de França e mostra para nós leitores como o professor ensaísta ao longo do romance se reconstrói ${ }^{5}$ a si mesmo. É essa reconstrução justamente que pensamos ser o ideal primeiro do romance em análise. O objetivo seria, então, resgatar o modo de viver a experiência narrativa já perdida nos leitores pós-modernos. Vale ressaltar que Osman Lins opta

5 A reconstrução se dá, paradoxalmente, pela descontrução de seu modo vida, explicitando-se, inclusive, no discurso. 
por usar a palavra "percepção das narrativas". A escolha não é aleatória, pois o substantivo deriva de perceber. A raiz latina do verbo é percipere ${ }^{6}$ significa "apoderar-se de", "apreender pelos sentidos".

Mas, qual seria a técnica utilizada para perceber a narrativa? Osman Lins, embora exponha a necessidade de resgatar um modo de apreensão perdido na modernidade, incorpora ao seu discurso técnicas consideradas inovadoras da composição narrativa no século XX: o monólogo interior e o fluxo de consciência.

Estudiosos da literatura estão de acordo que não é fácil distinguir esses recursos. No entanto, é possível ver que para o monólogo o discurso é mais organizado. Mas, como afirma Chiappini (2006:67): “O monólogo como forma direta e clara de apresentação dos pensamentos e sentimentos das personagens é muito antigo. Nós o encontramos, por exemplo, em Homero, na Odisséia". Já o fluxo de consciência mostra de forma desarticulada o discurso do narrador ou da personagem.

O livro de Osman Lins, de certo modo, pode-se dizer, traz também o surgimento desse tipo de técnica que surgiu a partir do momento em que os escritores compreenderam que a modernidade fragmentara o sujeito e o mundo, rompera a linearidade do tempo e encurtara as distâncias. Dos dias iniciais do diário, quando explicita que se ocupar do livro oferecer-lhe-á a vantagem de não se embaraçar entre recordações e imagens conservadas (LINS, 1976:2), até o último dia em que a invasão holandesa em Recife se passa em meados da década de 70; em que Olinda e Recife invadem São Paulo; em que o discurso de Maria de França invade o discurso do professor, vê-se como a consciência (ou diríamos inconsciência) do narrador ganha um fluxo tão similar a Leopold Bloom, de Ulysses.

O que se pode, então, esclarecer sobre o dispositivo de mediação antes de passar às considerações sobre Alcmena, é que Osman Lins expõe, na análise que o professor faz do romance de Julia, o processo de desenvolvimento de seu próprio romance. Para isso, incorpora a evolução das diferentes técnicas criadas durante o desenvolvimento da épica desde sua aparição com Ilíada e Odisséia.

\subsection{Alcmena: da carne ao verbo}

Como expusemos no início desta seção, em A rainha..., várias são as formas de mediação porque há histórias dentro da história. Como a todo instante há um jogo de reflexos, há duas forças opostas que se unem, é inevitável que a mediação aconteça de distintas formas. Dentre as me-

Novo Dicionário Aurelkio Electrônico da Língua Portuguesa de 2004. 
diações que já destacamos, uma nos parece imensamente significativa e não pode deixar de ser analisada mais detidamente: a presença da sobrinha Alcmena.

Tal como ocorre em cenas do romance, a relação real-imaginário se dá de maneira a gerar outras situações reais e imaginárias, conforme expusemos páginas atrás. Alcmena faz a mediação justamente entre o presente e o passado, a cegueira e a visão, a dúvida e o esclarecimento. Ela descobre dois pontos fundamentais no romance de Julia Marquezim Enone: ele está estruturado com canções populares e a participação do tio no livro inteiro.

Insistiu em ler A Rainha dos Cárceres da Grécia e me surpreendeu com um testemunho: "Vejo o senhor no livro inteiro." Como eu protestasse um tanto ansioso, esclareceu: "Não que eu o reconheça em alguma das pessoas. Mas está aqui." Observou também que versos inteiros de canções populares brasileiras permeiam de uma ponta a outra o texto, tendo-me apontado exemplos. (LINS, 1977: 87).

Para usar o estilo de Julia: Atenção, ouvintes, lembrem a origem de Alcmena: a menina veio do Espírito Santo! Ela veio para obscurecer e iluminar, dar morte e vida ao professor. Às vésperas do Natal.

Após ter ficado bastante contente com a notícia da visita da sobrinha, o professor, no dia 23 de dezembro de 1974 narra, em pouquíssimas linhas, os dias natalinos vividos com ela em Serra Negra. Essa data talvez seja a primeira em todo romance em que a vida dele não esteja rodeada por autores, críticos e o manuscrito da amante. Por isso afirma: “(...) ela, a portadora insconsciente de uma breve estação de calor e ociosidade em minha rotina apenas aquecida, hoje em dia, pelos autores que amo." (LINS, 1977:84)

Nesse dia, ela está no quarto ao lado; toda a viagem foi marcada por "fortes aguaceiros" (p. 84). Como se sabe, o espaço é um elemento importantíssimo para Osman Lins.7 A viagem a Serra Negra, sob chuva, pode ter vários significados. A chuva, ao invés de atrapalhar o caminho, funciona como elemento purificador que o dará um modo de vida distinto daquele vivido nos últimos meses, ainda que momentâneo. E não surpreende que a provável mudança esteja sendo feita às vesperas do natal, momento de reflexão, nascimento, esperança. Não surpreende porque, afinal, Alcmena é "vinda do Espírito Santo" (LINS, 1977:84).

\footnotetext{
Sua tees de odutoramento é trata justamente da relação espaço e personagem na obra literaría. Aliás, é a Osman Lins que se deve a conceito de ambientação. Cf Lima Barreto e o espaço romanesco.
} 
A próxima data registrada no diário é 24 dezembro, à meia-noite, durante a ceia de natal. Em meio a reflexões sobre a absorvição de costumes natalinos estranhos e alheios à tradição brasileira (músicas, pinheiros, castanhas, tâmaras e damascos), de repente, como é comum em todo o romance, muda de assunto sem que, a priori, haja relação entre o anterior e o que se segue. Passa a falar de Alcmena. Os gestos da sobrinha são descritos de maneira que não parece ter a ver relação entre as tradições natalinas européias e sua reflexão. No entanto, conclui que "o homem nunca é imune-antes, vulnerável-às especiarias, às essências aromáticas e aos animais trazidos de longe." (LINS, 1977:85)

Todo trabalho crítico de revelar a seu leitor (e a si mesmo) os signos que compõem o livro de Julia não está presente quando fala da sobrinha - assim como sempre que narra algo acontecido consigo.

Neste instante, uma relação incestuosa começa a se desenhar e tornarse, por assim dizer, clara no 6 de janeiro de 1975. Ainda que apenas insinuada para nós leitores, podemos perceber que a presença da sobrinha o torna vulnerável "as essências aromáticas" (LINS, 1977:85).

Em 6 de janeiro, é justamente o dia do aniversário de Julia Enone, quando ela completaria 35 anos. É sobre isso que estão conversando: sobre Julia. A conversa é entrecortada por indicações do que está fazendo Alcmena e não apenas o que ela fala. Aliás, podemos dizer que são as falas que entrecortam os seus gestos. As mãos no cabelo, a estrela no céu ${ }^{8}$, a perna de Alcmena estendida, tudo parece convergir para uma relação incestuosa, se não física, pelo menos psíquica.

O primeiro gesto de Alcmena, descrito pelo professor, é que ela “levantou devagar um braço e apanhou, com os seus longos dedos abertos em leque, alguns cabelos que lhe caíam pela testa." A cena é cinematográfica e carregada de simbologia. O cabelo feminino serve como elemento de sedução e insinuação principalmente quando solto. Logo após a pergunta sobre os filhos de Julia, temos o primeiro referente espacial: "a sala estava quase em treva completa". Neste instante, outro elemento de sedução e insinuação aparece: os olhos. Nesta quase treva completa, o tio só vê "o grande olhar" que o envolvia todo.

Outra referência ao ambiente é feita quando Alcmena está olhando-o fixamente e esperando uma resposta sobre a filha de Julia. "Uma estrela brilhava muito próxima das nossas cabeças." (LINS, 1977:86).

86 de janeriro é dia de reis, o seja, o dia em que, segundo a tradição judaica-cristã, o s reis magos souberam do naswcimento de Jesus pela estrela de Belém. 
Alcmena, na mitologia grega, representa as mulheres fortes, que sempre lutam pela própria honra. Significa, segundo Brandão (2000, p. 50): "repelir o inimigo, afastar o perigo, defender". Ela foi enganada por Zeus, com quem teve três noites de amor, já que esse se fizera de Anfitrião, primo e esposo de Alcmena. Também em três foi o número de tempo passado entre sobrinha e tio, só que semanas e não dias.

Hugo Afonso de Almeida Souza, em sua tese de doutoramento pela Universidade de São Paulo, destaca a presença do mundo grego no romance de Osman Lins. Leitura inédita, o autor faz uma ampla explanação sobre os motivos e personagens gregos que perpassam o romance do início ao fim. Ressalta que até a topografia do Recife e de Olinda se assemelha à da Grécia (SOUZA, 2005:49).

Como não poderia deixar de ser, a importância de Alcmena para a narrativa também é destacada: "após a revelação de Alcmena, o narrador passa a se perguntar: 'Quem sou?'" (SOUZA, 2005:53). A pergunta, aliás, torna-se recorrente e aparece várias outras vezes, sobretudo no último dia de registro do diário.

Contrariamente a Souza, no entanto, acreditamos que os mitos presentes em Osman Lins aparecem com características mudadas. Alcmena, a sobrinha, não repele o inimigo nem afasta o perigo, como acontece com sua homônima mitológica. Ela, pelo contrário, dá forças para que o tio vá até o inimigo, ao perigo: o livro de Julia. Sua presença é marcante, mas não consegue mudar o fim para o qual o tio caminha. A relação incestuosa insinuada reforça a idéia de que o professor está tão preso a Julia e seu manuscrito que ele já não consegue se livrar. A única que talvez pudesse livrá-lo, afastá-lo do perigo, não consegue, porque vai embora e, mais importante, reforça aquilo que ele quer ouvir: que ele está dentro do livro. No romance de Lins, Alcmena não luta; ao contrário da Alcmena mítica, que sempre persiste em cuidar de si, dos filhos e dos netos.

Alcmena, como se vê, é mediadora: interpõe-se entre o livro e o narrador; faz também a intermediação entre o desconhecido e o conhecido para o tio. No conjunto da obra, ela está adaptada perfeitamente. Se fossem retomadas as definições do Novo Dicionário Aurélio Eletrônico, seria possível verificar que Alcmena é uma terceira pessoa que estabelece a relação entre seu tio e o livro, entre o estudioso e o conhecimento. Lembrando sempre que o professor busca se conhecer. Se no início de seu diário tinha claramente a idéia de que escreveria um ensaio, a partir da convivência com a sobrinha envereda-se por outro caminho. O racionalismo proposto pelo ensaio cede espaço a experiência transcendental causado pelo convívio com o romance. 


\section{Considerações finais}

Este trabalho, sobre o qual será colocado um ponto final daqui a algumas linhas, está longe de terminar. Fruto mais da análise pessoal e convivência com o romance de Osman Lins do que da pesquisa e de incorporação de referencias teóricos sobre a narrativa, pretendeu-se ler o romance enfatizando sua ligação com a evolução da narrativa e os procedimentos de criação utilizados por Osman Lins. Como principal procedimento, destacamos o processo de mediação, que se insere dentro dos estudos sobre o narrador. Com tal recurso, o escritor pernambucano explora vários temas, entre eles o momento ditatorial brasileiro, a produção literária brasileira e o modo de vivenciar um texto literário.

A partir dos temas questionados, pergunta-se: é possível falar de uma crise da crítica ou do romance? Não cremos nisso. Mais bem nos parece que essas discussões sirvam para mostrar que o romance não está morrendo. Ou pelo menos a forma tradicional não existirá (existe?) mais. Então, criar uma obra que dê conta das complexidades existentes no mundo contemporâneo exige novas formas de criação e, por conseguinte, novas teorias para tentar interpretá-las.

Osman Lins estava consciente disso. Mas estava consciente também de que o convívio com a obra é essencial para compreendê-la e percebêla. Osman Lins tenta dissuadir seu leitor, levando-o a crer que a temática central está no romance de Julia Marquezim Enone. As personagens, as metáforas, os símbolos, as ações que mais se sobressaem fazem parte do romance da amante. O professor de ciências naturais é um homem tentando desvendar sua vida pelo livro da amante, tanto que acaba se confundindo com o espaço do romance, se transformando em uma de suas personagens. No entanto, está tão cego pela leitura do livro que não percebe que sua vida está rodeada de símbolos e metáforas que ou não dá importância ou não quer registrar no diário. Quando registra os fatos e vê neles algum significado, não se estende, apenas apresenta sutilmente fazendo, assim, que se construa uma narrativa e não mais o ensaio.

\section{Referência bibliográfica}

Benjamin, Walter (1994). "O narrador", Obras escolhidas: Magia e técnica, arte e política. Tradução: Sergio Paulo Rouanet. 7.ed. São Paulo: Brasiliense, p. 197-221.

Dias, Maria Teresa (1997). Entre a arte e a vida (um estudo de A rainha dos cárceres da Grécia de Osman Lins). (1997) Dissertação (Mestrado) - USP. 
O posicionamento do narrador em A rainha dos cárceres da Grécia de Osman Lins /

Robson Hasmann

Leite, Ligia Chiappini Moraes (2006).

O foco narrativo (ou A polêmica em torno da ilusão). 10. ed. São Paulo: Ática.

Lins, Osman (1977). $\quad$ A rainha dos cárceres da Grécia. 2.ed. São Paulo: Melhoramentos.

Nitrini, Sandra (1987). Poéticas em confronto: Nove, novena e o Novo Romance. São Paulo: HUCITEC; Brasília: INL, Fundação Nacional Pró-Memória.

Souza, Hugo Afonso de Almeida.

Osman Lins: A chama grega do cárcere Brasil (2005). 196 p. Tese (Doutorado) - USP. 